\title{
IMPROVEMENT OF TEACHER PEDAGOGICAL COMPETENCE THROUGH IN HOUSE TRAINING ACTIVITIES
}

\author{
Akhmad Fadil $^{1 *}$, Ine Kusuma Aryani ${ }^{2}$ \\ Universitas Muhammadiyah Purwokerto, INDONESIA
}

Received 30 May 2021 - Revised 26 August 2021 • Accepted 20 September 2021

\begin{abstract}
This study aims to determine the effect of In House Training (IHT) in increasing teacher pedagogical competence. Pedagogic competence is one of the teacher competencies which have an important vital role in achieving student learning outcomes quality. If the teacher's pedagogical competence is low, it may affect the learning outcomes of students. One of the efforts is through activities to increase teacher pedagogical competence. One of the activities to increase teacher competence is through training. The most effective and efficient competencies improvement training model is In House Training (IHT). This training can accommodate teacher training needs with easy access. The type of data used is secondary data. The method used in this research is the literature study method. The data obtained were collected, analyzed, and concluded to get conclusions about the literature study. Based on the research results, literature studies from several research results and journal articles show that In House Training activities can improve teacher pedagogical competence.
\end{abstract}

Keywords: In House Training, Pedagogic Competence.

\section{INTRODUCTION}

The role of the teacher in transforming educational inputs is very significant. It is inseparable from the existence of a schooling system that includes input-process-output, where the teacher as one of the input factors plays an essential role in the process to produce the result in following the expectation.[9]. To carry out a quality process, the teacher's competence must be qualified. The teacher's competencies strongly influence the quality of education.

Competencies are the skill and knowledge that enable a teacher to be successful [1]. Competent teachers are needed to create the students' character. Therefore, the government should optimize the teachers' competencies. There are still many problems related to teacher competencies. As conveyed in the news (Britagar. id), the "report card" of Indonesian teachers in the Teacher Competencies Test (UKG) since 2015, the average until 2017 is still below 70 of the maximum value of 100 . The material tested in UKG is pedagogic competence and professional competence. This shows that the pedagogic competence of teachers is still low. For this reason, efforts are needed to improve. The Ministry of Education and Culture has carried out regular academic measurements every time. Year through the Teacher Competencies Test (UKG), and non-academic measures by assessing teacher performance.

The Teacher Competencies Test is a test of mastery of professional and pedagogical competencies in the cognitive domain as a basis for building continuous professional development activities and part of teacher assessment.[4]. In general, teacher pedagogic knowledge affects student learning outcomes positively, and hence, it is not surprising that teacher preparation and certification measures, as indicators of teacher knowledge and skills, are the most vital factors of student achievement in reading and mathematics [1].

One way to improve teacher competencies in the pedagogical field is to increase teachers' understanding and knowledge of local wisdom in learning. To overcome this problem, of course, requires a strong commitment from policymakers, in this case; the central government. Teacher training is needed to improve teacher competencies, especially competencies related to the learning process, namely pedagogical competencies.

Ghafoor, Ahmed, \& Aslam [14]in their study, states that training has a significant effect on organizational performance. So far, the opportunity to participate in training organized by the government for teachers is minimal [2]. Training programs on improving teacher competencies from the center have not reached all teachers in the country. Training is a widely accepted and systematic practice for professional development. It helps people gain the basic levels of mindset, understanding and, abilities[3]. 
Internal training programs are most effective for the long-term success of an organization's strategic objectives [4]. An internal training program that can be applied to answer this problem is the In House Training model. In House Training is a training program that is held in its place, as an effort to improve teacher competencies in carrying out work by optimizing existing potentials [5]. In implementing In House Training, teachers can freely choose the training subjects that are considered the most important. Determination of training programs carried out with a needs analysis can also assist teachers in overcoming daily difficulties encountered during teaching[6].

The approaches for training and education that teachers have changed over time. In this case, Grenfell said, "the early common senses notion of teaching by doing have been replaced by more descriptive 'how to teach' techniques in line with current methodological trends"[7]. The teacher training program is expected to correct the misperceptions of most teachers about the status of textbooks and strengthen the capacity of teachers to develop their teaching and learning materials complementing what has been discussed in the books.[7].

After gaining training experience on improving academic competencies, that is hoped that teachers will have more provisions related to their tasks in the learning process. This provision will become a weapon for teachers in improving the quality of learning in their respective classes.

\section{METHOD OF THE RESEARCH}

This research is a literature review research. The data used in this study is secondary data. Secondary data is data that is not be taken from direct observation but the results of previous research. The method used on this research is Documentation, The documentation method is a systematic data collection procedure for reviewing printed and electronic documents.

The documentation method is a data collection method which is done by finding or extracting data from literature related to what is meant in the problem formulation. And for The data analysis used in this research is bibliographic annotation analysis. Annotation indicates a simple conclusion from an article, book, journal, or some other written sources, while a bibliography is defined as a list of sources of a topic. The documentation method is a systematic data collection procedure for reviewing printed and electronic documents [8].

The documentation method is a data collection method that is done by finding or extracting data from literature related to what is meant in the problem formulation. The data analysis used in this research is bibliographic annotation analysis. Annotation indicates a simple conclusion from an article, book, journal, or some other written source, while a bibliography is defined as a list of the source of a topic.[9].

\section{RESULT AND DISCUSSION}

Basri explained that In House Training is a training program that occurs at the request of a particular community, both for-profit and non-profit organizations [10]. The same thing is also expressed by Corinorita, which stated that In House Training is a training program held in place, as an effort to improve teacher competencies, in carrying out their work by optimizing existing potentials [8].

In the national education standards [11], The explanation of article 28 paragraph (3) point (a) states that what is meant by pedagogic competencies is the ability to manage student learning, including understanding students, designing and implementing learning, evaluating learning outcomes, and developing students to actualize their various potentials.

This condition, in Mulyasa's review at least includes the following aspects [12], namely: (a) understanding of educational insights and foundations, (b) understanding of students, (c) developing curriculum/ syllabus, (d) learning design, (e) implementing educational learning and dialogical, (f) the use of learning technology, (g) evaluation of learning outcomes (EHB), and (h) the development of students to actualize their various potentials.

When we evaluate a various training program for national policy products which is used as a tool to improve a teacher competencies, in reality, they are also entirely adopted by the regions, or there is a kind of 'weakness' in the determination of training programs both in the field of model and implementation. A particular training model can be implemented effectively by teachers in certain sites, but it is not necessarily effective if it is applied to other areas that have different characteristics and problems, or it may not possible for the same training model to be provided to teachers in urban primary schools and teachers in remote areas, in reality, the needs of teachers and their level of competencies are very different.

The characteristics of remote areas appear with distinctive geographical, socio-cultural, and educational aspects so that they require a separate approach in handling their education [13]. House Training (IHT) provides an opportunity for teachers to obtain the same rights according to their needs. This training model has advantages of the same needs in an organization that is in the same environment. The results of data show that the training participants receive the materials given by the trainer well, they are enthusiastic about joining the training and get many benefits from it [14].

(C) 2021 by the authors; licensee PGSD UMP. This article is an open access article distributed under the terms and conditions of the Creative Commons Attribution License (http://creativecommons.org/licenses/by/4.0/). \. fadiel588@gmail.com ${ }^{1}$, inepascapendas@gmail.com (*Correspondence) 
Optimization of in-house training is very influential in increasing teacher competencies in teaching [6]. After the In house Training activities have been held, the teacher became active in evaluating their performances and discussing problem-solving related to the cases found during the teaching and learning process in their class [14-16]. In House Training gives experiences for teachers in designing effective, efficient, and purposeful learning. Arranging the lesson plan then developing it by choosing the media and learning methods becomes the teacher's valuable experience before the learning process is carried out [7][17-18].

To optimize the training, the school must pay attention to the stages of its management, as well as the factors that will support the success of the training. The management stage includes: The planning stage, initially carried out by analyzing the needs of educators and education personnel in the context of competencies and determining the implementation team. Training planning activities include planning training schedules, some participants, determining material, media, place, resource persons or presenters, planning implementation activities, planning training evaluations, and planning funds [19-20].

\section{CONCLUSION}

Based on the background of the research results from the literature study presented, it can be concluded that In House Training is effective to improve teachers' pedagogic competencies. Problems in improving pedagogic competence can be overcome in in-house training forums. In-house training can also provide motivation and confidence for teachers in unraveling their weaknesses, especially pedagogic competencies. The results of data show that the training participants receive the materials given by trainer well, they are enthusiastic in joining the training, and get much benefits from it. So, based from the data result shows, we can conclude that In House Training is effective to improve teachers' pedagogic competencies and I really recommend it to be held routinely in every school. The author hopes that this paper can be an alternative study for teachers and related parties in overcoming the problem of the low pedagogical competencies of elementary school teachers..

\section{REFERENCES}

[1] Pit-ten Cate, I. M., Markova, M., Krischler, M., \& Krolak-Schwerdt, S. (2018). Promoting Inclusive Education: The Role of Teachers' Competence and Attitudes. Insights into Learning Disabilities, 15(1), 49-63.

[2] Widodo, S. (2020). Peningkatan Kompetensi guru Pada Penerapan Pelaksanaan Pembelajaran Yang Interaktif, Inspiratif, Menyenangkan, Menantang, Memotivasi Melalui In House Training Di SMA Negeri 1 Ulujami. JOURNAL SCIENTIFIC OF MANDALIKA (JSM) e-ISSN 2745-5955, 1(3 Oktober), 225-233.

[3] Islam, R. (2020). Enhancing Instructional Leadership using in-House Training. i-Manager's Journal of Educational Technology, 17(2), 14.

[4] Sudarto, T., Asmawi, M., Yasin, M., \& Suratman, A. (2019). Evaluation of Training Program for Warehouse Manager Candidates within the Warehouse Receipt System Scheme at Commodity Future Trading Regulatory Agency (COFTRA) Indonesia. International Journal of Mechanical Engineering and Technology, 10(3), 525-542

[5] Astuti, S., Slameto, S., \& Dwikurnaningsih, Y. (2017). Peningkatan kemampuan guru sekolah dasar dalam penyusunan instrumen ranah sikap melalui in house training. Kelola: Jurnal Manajemen Pendidikan, 4(1), 37-47.

[6] Puspitasari, R., \& Budiningsih, C. A. (2020, December). In House Training Optimization: Efforts to Improve Teacher Quality. In 2nd Yogyakarta International Conference on Educational Management/Administration and Pedagogy (YICEMAP 2019) (pp. 179-185). Atlantis Press.

[7] [7] Lengkanawati, N. S., Setyarini, S., Sari, R. D. K., \& Moecharam, N. Y. (2015). In house training (IHT) model to improve the abilities of English teachers in developing teaching materials. Indonesian Journal of Applied Linguistics, 5(1), 37-43.

[8] Corinorita, C. (2017). Pelaksanaan In House Training Untuk Meningkatkan Kompetensi Guru dalam Menyusun RPP Di Sekolah Menengah Pertama. Suara Guru, 3(1), 117-122.

[9] Bowen, G. A. (2009). Document Analysis as a Qualitative Research Method. Qualitative Research Journal, 9(2), 27-40. https://doi.org/10.3316/QRJ0902027.

[10] Basri, H., \& Rusdiana, A. (2015). Manajemen Pendidikan dan Pelatihan. Bandung: Pustaka Setia.

[11] Peraturan Pemerintah No. 19 Tahun 2005. Tentang Standar Nasional Pendidikan.

[12] Mulyasa, E. 2007. Standar Kompetensi Sertifikasi Guru. Bandung: PT. Remaja Rosdakarya.

[13] Nugroho, P. J. (2017). Pengembangan model pelatihan inovatif untuk meningkatkan kompetensi guru SD daerah terpencil. Sekolah Dasar: Kajian Teori dan Praktik Pendidikan, 26(2), 101-115.

[14] Suhelmidam. (2019). Improvement of Teacher Capability Using Contextual Teaching and Learning Models Through in House Training. Journal of Educational Sciences 3 (3), 281-291

[15] Arpius, A. (2020). EFFORTS TO IMPROVE TEACHERS'COMPETENCE IN PREPARING LESSON PLAN DURING THE COVID-19 PANDEMIC THROUGH IN HOUSE TRAINING. JURNAL PAJAR (Pendidikan dan Pengajaran), 4(6), 1259-1266.

[16] Erman, E. (2020). In House Training Meningkatkan Kompetensi Guru SMPN 5 Rakit Kulim dalam Pembelajaran Jarak Jauh. Jurnal Pendidikan Tambusai, 4(3), 3442-3449. 
[17] Febrianis I, Muljono P, Susanto D. (2014). Pedagogical competencies-based Training Needs Analysis for Natural Science Teachers. Journal of Education and Learning, 8(2),144-151.

[18] Khaerani, N. C. (2016). Peningkatan Kompetensi Guru dalam Menyusun RPP melalui Kegiatan IHT (in house training). Didaktikum, 17(1).

[19] Susanto, R., Rozali, Y. A., \& Agustina, N. (2019). Development of pedagogical competency models for elementary school teachers: Pedagogical knowledge, reflective ability, emotional intelligence and instructional communication pattern. Universal Journal of Educational Research, 7(10), 2124-2132..

[20] Syahrial, S., Asrial, A., Kurniawan, D. A., Chan, F., Hariandi, A., Pratama, R. A., ... \& Septiasari, R. (2019). The Impact of Etnocontructivism in Social Affairs on Pedagogic Competencies. International Journal of Evaluation and Research in Education, 8(3), 409-416.

\section{http://jurnalnasional.ump/index.php/dinamika}

